\title{
Evaluation of Transforming Growth Factor- $\beta$ Signaling Pathway in the Wall of Normal and Varicose Veins
}

\author{
Radoslaw Kowalewski ${ }^{a} \quad$ Andrzej Malkowski $^{b} \quad$ Krzysztof Sobolewski $^{b}$ \\ Marek Gacko ${ }^{a}$ \\ Departments of a Vascular Surgery and Transplantology, and ${ }^{b}$ Medical Biochemistry, Medical University of \\ Bialystok, Bialystok, Poland
}

\section{Key Words \\ Chronic venous insufficiency - Varicose veins . \\ Transforming growth factor- $\beta_{1} \cdot$ Transforming growth \\ factor $-\beta$ receptor type $I I \cdot$ Smad}

\begin{abstract}
Objective(s): Extracellular matrix remodeling in the vein wall is involved in varicose vein pathogenesis, with transforming growth factor $\beta_{1}$ (TGF- $\beta_{1}$ ) playing a potential role. The aim of the study was to assess the TGF- $\beta$ signaling pathway including its receptor (TGF- $\beta$ RII) and phosphorylated receptor-regulated Smads ( $\mathrm{p}-\mathrm{Smad} 2 / 3)$ in varicose veins. Methods: Varicose veins from patients undergoing varicose vein surgery were the studied material, whereas normal greater saphenous veins from patients undergoing infrainguinal arterial bypass surgery were the control material. Expression of TGF- $\beta$ RII mRNA was assessed with RT-PCR, whereas expression of TGF- $\beta$ RII and $p$-Smad $2 / 3$ proteins was assessed with Western blot. Results: A significantly increased TGF- $\beta$ RII mRNA level was found in varicose veins $(287 \pm 24 \%)$, when compared with normal veins (100 \pm $26 \%)$. The receptor protein expression reflected a changed mRNA level with significantly increased TGF- $\beta$ RII protein in varicose veins ( $290 \pm 21 \%)$, when compared with controls $(100 \pm 16 \%)$. Enhanced TGF- $\beta$ RII expression was accompanied by increased $\mathrm{p}-\mathrm{Smad} 2 / 3$ protein expression in varicose
\end{abstract}

veins $(257 \pm 19 \%)$ in comparison with normal veins (100 \pm 9\%). Conclusion(s): Increased TGF- $\beta$ RII expression and activation in the wall of varicose veins may be involved in extracellular matrix remodeling related to TGF- $\beta_{1}$ and supports its role in the disease pathogenesis.

Copyright $\odot 2010$ S. Karger AG, Basel

\section{Introduction}

Varicose veins are among the most common features of chronic venous insufficiency (CVI), which exerts a high impact on patient quality of life [1]. The disease pathogenesis is still not clearly understood. Although valvular incompetence, alterations in smooth muscle cell arrangement and changes in extracellular matrix (ECM) composition are the most commonly noted factors affecting the development of varicose veins, the exact mechanisms through which they interact in the disease pathogenesis remain unknown $[2,3]$.

ECM is a complex supramolecular structure and its remodeling contributes to weakness and reduced elasticity of the varicose vein wall $[2,4]$. Transforming growth factor $\beta$ (TGF- $\beta$ ) has a profound effect on the synthesis and degradation of a large number of ECM molecules, including different types of collagen and proteoglycans. It also influences the synthesis of matrix metalloprotein-

\section{KARGER}

Fax +4161306 1234

E-Mail karger@karger.ch

www.karger.com (c) 2010 S. Karger AG, Basel

$1015-2008 / 10 / 0771-0001 \$ 26.00 / 0$

Accessible online at:

www.karger.com/pat
Radoslaw Kowalewski, MD

Department of Vascular Surgery and Transplantology Medical University of Bialystok

M. Curie Sklodowskiej 24 A St., PL-15-276 Bialystok (Poland)

Tel. +48 85746 8277, Fax +48 85746 8896, E-Mail korado@2com.pl 
ases and their inhibitors [4]. Among its 3 isoforms, TGF$\beta_{1}$ plays a crucial role in vessel wall remodeling $[5,6]$. Thus, the growth factor has been extensively studied in CVI pathogenesis, and increased TGF- $\beta_{1}$ mRNA levels, as well as its protein content, were found in the wall of varicose veins in comparison with normal veins [7-9].

TGF- $\beta_{1}$ is synthesized as an inactive molecule, and numerous proteases are involved in latent TGF- $\beta_{1}$ activation [10]. An active form of TGF- $\beta_{1}$ acts through membrane serine/threonine kinase receptors of type I and II [5]. The latter are expressed constitutively, whereas TGF$\beta$ RI is recruited after TGF- $\beta$ binding to the type II receptor $[5,11]$. Thus, the presence of TGF- $\beta$ RII is essential to cellular responsiveness to TGF- $\beta_{1}$ [12]. Once the receptor complex is activated, it leads to intracellular Smad protein phosphorylation. Phosphorylated receptor-regulated Smads (p-Smad2 and p-Smad3) are transported into the nucleus and regulate gene transcription, including synthesis of collagen or tissue inhibitors of metalloproteinases [5]. However, in spite of the commonly accepted role of TGF- $\beta_{1}$ in varicose vein pathogenesis, the TGF- $\beta$ signaling pathway has not been evaluated in the vein wall.

The aim of the study was to assess TGF- $\beta$ RII mRNA and protein expression, as well as $\mathrm{p}-\mathrm{Smad} 2 / 3$ protein expression in the wall of varicose veins and normal controls.

\section{Materials and Methods}

The investigation protocol conforms to the principles outlined in the Declaration of Helsinki and was approved by the Committee for Ethics and Supervision on Human and Animal Research of the Medical University of Bialystok, Bialystok, Poland. Patients on preoperative therapy with statins were excluded from the study [13]. All patients enrolled in the research provided informed consent after reviewing the study protocol.

\section{Tissue Material}

The varicose vein specimens were collected from patients undergoing varicose vein surgery. Patients with duplex evidence of greater saphenous vein (GSV) thrombosis, deep vein reflux, current or previous deep vein thrombosis, or a history of previous sclerotherapy were excluded from the study. Twenty-four patients with primary varicose veins were enrolled in the research (16 women and 8 men; mean age $52.9 \pm 9.2$ years, range $43-66$ ). All of them were in class 2 according to the clinical signs of the CEAP classification. All patients exhibited saphenofemoral junction incompetence with reflux in the proximal femoral region of the GSV. The lesser saphenous vein was affected in 2 patients (8\%). The control material consisted of GSV specimens harvested from the distal femoral region in 12 patients ( 8 women and 4 men; mean age $57 \pm 5.1$ years, range $48-65)$ with chronic limb isch- emia undergoing infrainguinal arterial bypass surgery. Control patients had no history of venous disease or evidence of vein reflux.

\section{RT-PCR Analysis}

A total of $50 \mathrm{mg}$ of harvested tissue was pulverized after immersion in liquid nitrogen. RNA was extracted from tissues via the AxyPrep Multisource Total RNA Miniprep Kit (catalogue number AP-MN-MS-RNA-50; Axygen Bioscience, Union City, Calif., USA). The total RNA concentration was determined by measuring the optical density at $260 \mathrm{~nm}$. The ratio of A260/A280 was greater than 1.8. The RNA quality was checked by electrophoresis in a $1.2 \%$ agarose gel, followed by staining with ethidium bromide and examination of the $28 \mathrm{~S}$ and $18 \mathrm{~S}$ rRNA bands with an UV transilluminator. No significant degradation was observed in any RNA sample.

A total of $3 \mu \mathrm{g}$ of total RNA was reverse-transcribed into cDNA with the use of a RevertAid ${ }^{\mathrm{TM}}$ First Stand cDNA Synthesis Kit (catalogue number K1622; Fermentas, Vilnius, Lithuania) and oligo $(\mathrm{dT})_{18}$ primers.

For cDNA amplification, the following pairs of primers were used: (1) forward human TGF- $\beta$ RII $5^{\prime}$-AGCAGAAGCTGAGTTCAACCTGGG-3'/reverse human TGF- $\beta$ RII $5^{\prime}$-GGAGCCATGTATCTTGCAGTTCC-3'; (2) forward human TGF- $\beta$ RII 5'-AATATCCTCGTGAAGAACGA-3'/reverse human TGF- $\beta$ RII 5'-CAGTCAACGTCTCACACACC-3', and (3) forward human $\beta$-actin $5^{\prime}$-TTGTAACCAACTGGGACGATATGG-3'/reverse human $\beta$-actin $5^{\prime}$-GATCTTGATCTTCATGGTGCTAGG3 '. Two pairs of TGF- $\beta$ RII primers were used to eliminate the possibility that final RT-PCR products may originate from genomic DNA contaminations. All primers were synthesized by Sigma-Proligo (St. Louis, Mo., USA).

Aliquots of $5 \mu \mathrm{l}$ of the cDNA and $20 \mathrm{nM}$ of each primer were subjected to PCR using Taq DNA polymerase (catalogue number EP0402; Fermentas). PCR thermocycling conditions for TGF- $\beta$ RII and $\beta$-actin cDNA detection were set up as follows: 1 cycle of denaturation at $94^{\circ} \mathrm{C}$ for $4 \mathrm{~min}, 30$ cycles of $94^{\circ} \mathrm{C}$ for $1 \mathrm{~min} / 60^{\circ} \mathrm{C}$ for $1 \mathrm{~min} / 72^{\circ} \mathrm{C}$ for $1 \mathrm{~min}$, and a final primer sequence extension incubation at $72^{\circ} \mathrm{C}$ for $10 \mathrm{~min}$. Ten microliters from each amplification reaction was analyzed with electrophoresis in $2 \%$ agarose gels in the presence of $0.5 \mu \mathrm{g} / \mathrm{ml}$ ethidium bromide. DNA was visualized under UV light. Contamination was routinely checked by an RT-PCR assay of cDNA template-free samples (water control). The RT-PCR reaction products that were separated by agarose gel electrophoresis were photographed, scanned and analyzed using the QuantityOne software (Bio-Rad, Hercules, Calif., USA). The optical density of the TGF- $\beta$ RII bands was normalized to the corresponding $\beta$-actin bands. The gene expression ratios were normalized to $100 \%$ in control veins, whereas in varicose veins, they were expressed relative to control veins.

\section{Western Blot Analysis}

Collected samples were washed with ice-cold $0.9 \% \mathrm{NaCl}$ solution, cut, weighed and suspended in $0.15 \mathrm{M}$ Tris- $\mathrm{HCl}$ buffer $(\mathrm{pH}$ $7.4)$ in the ratio $1: 3(\mathrm{w} / \mathrm{v})$. The homogenates were prepared with a knife homogenizer $\left(25,000 \mathrm{rpm}\right.$ for $45 \mathrm{~s}$ at $\left.4^{\circ} \mathrm{C}\right)$ and sonicated $(20$ $\mathrm{kHz}, 4 \times 15 \mathrm{~s}$ at $\left.4^{\circ} \mathrm{C}\right)$. After centrifugation $(10,000 \mathrm{~g}$ for $15 \mathrm{~min}$ at $\left.4^{\circ} \mathrm{C}\right)$, supernatants were stored at $-70^{\circ} \mathrm{C}$ until measurements were performed. The protein content was determined according to the method described by Bradford [14], and SDS/PAGE was 
performed according to the method described by Laemmli [15]. Samples of tissue supernatants containing $20 \mu \mathrm{g}$ of protein were subjected to electrophoresis. The following molecular mass standards were used: 208, 120, 99, 53, 43, 37 and $29 \mathrm{kDa}$ (catalogue number 1610318; Bio-Rad). The gels were allowed to equilibrate in $25 \mathrm{~mm}$ Tris, $0.2 \mathrm{M} \mathrm{L}$-glycine, $20 \%(\mathrm{v} / \mathrm{v})$ methanol for $5 \mathrm{~min}$, and the proteins were transferred to $0.2 \mu \mathrm{m}$ pore diameter nitrocellulose membranes at $100 \mathrm{~mA}$ for $1 \mathrm{~h}$. The membranes were then incubated in $5 \%$ dried defatted milk in TBST $[20 \mathrm{mM}$ Tris- $\mathrm{HCl}$ buffer, $\mathrm{pH}$ 7.4, $150 \mathrm{~mm} \mathrm{NaCl}, 0.05 \%$ (v/v) Tween 20] for $1 \mathrm{~h}$ with one of the following primary antibodies: (1) polyclonal anti-human TGF- $\beta$ RII antibody (goat IgG; catalogue number AF-241NA; R\&D Systems Inc., Minneapolis, Minn., USA) at 1:500 dilution; (2) polyclonal anti-human p-Smad2/3 antibody (goat IgG; catalogue number sc-11769; Santa Cruz Biotechnology Inc., Santa Cruz, Calif., USA) at 1:200 dilution, and (3) monoclonal anti-human actin antibody (mouse IgG; catalogue number sc-8432; Santa Cruz Biotechnology Inc.) at 1:200 dilution. Species-specific secondary antibodies were then added at 1:7,500 dilution. Incubation was continued for $30 \mathrm{~min}$ with slow shaking. After that, nitrocellulose membranes were washed with TBS-T (5 times for $5 \mathrm{~min}$ ) and treated with Sigma-Fast BCIP/NBT reagent (catalogue number B1911; Sigma Aldrich Chemie GmbH, Steinheim, Germany). Three measurements were performed in each tissue sample. The labeled membranes were photographed, scanned, and optical density was analyzed using an imagining QuantityOne software (Bio-Rad). The optical density of the TGF- $\beta$ RII and pSmad $2 / 3$ bands was normalized to the corresponding actin bands. The protein expression ratios were normalized to $100 \%$ in control veins, whereas in varicose veins, they were expressed relative to controls.

\section{Statistical Analysis}

Data are represented as the mean \pm standard deviation. The normal distribution of the obtained results was confirmed by a Kolmogorov-Smirnov one-sample test of normality, and descriptive exploration and analysis of Skewness. Statistical analysis of the obtained results was carried out using one-way or KruskalWallis analysis of variance (ANOVA). All tests were 2-tailed. $\mathrm{p}<$ 0.05 was considered statistically significant.

\section{Results}

RT-PCR analysis of the investigated tissues is shown in figure 1a. Only trace expression of TGF- $\beta$ RII mRNA was found in the wall of normal veins (line 1 ), whereas strong expression of TGF- $\beta$ RII mRNA was present in the wall of varicose veins (line 2). Densitometric analysis of TGF- $\beta$ RII mRNA expression is shown in figure $1 b$. TGF$\beta$ RII mRNA expression was significantly increased in the wall of varicose veins, when compared with the wall of normal veins $(\mathrm{p}<0.001)$. No significant difference in TGF- $\beta$ RII mRNA expression was found between both sets of measurements performed with different pairs of primers. Furthermore, gender-based evaluation did not

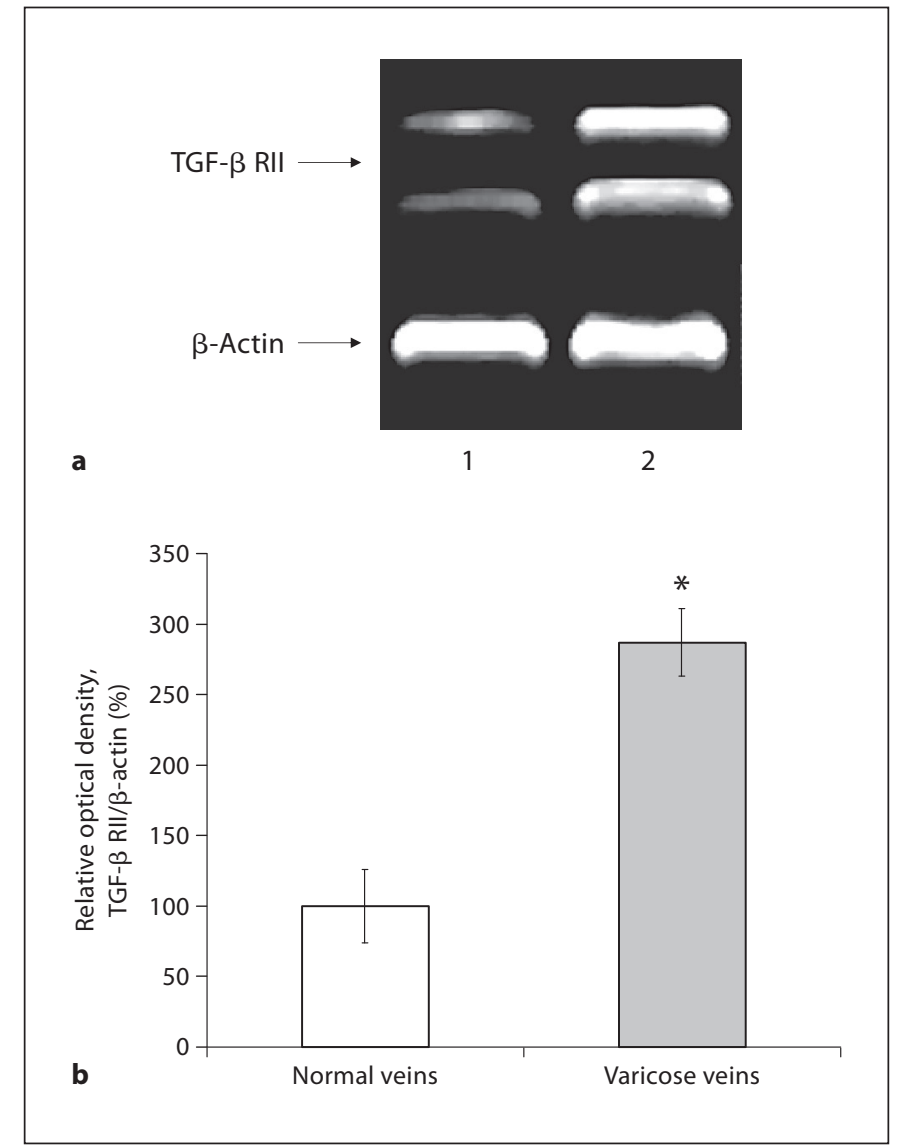

Fig. 1. a RT-PCR analysis of TGF- $\beta$ RII mRNA expression in the vein wall (lane 1 , normal veins; lane 2 , varicose veins). RNA ( $3 \mu \mathrm{g}$ ) was reverse-transcribed with the use of oligo $(\mathrm{dT})_{18}$ primers. $\mathrm{cDNA}$ amplification was performed with TGF- $\beta$ RII and $\beta$-actin primers. b Densitometric analysis of TGF- $\beta$ RII mRNA expression from 12 control samples and 24 varicose vein samples. The optical density of TGF- $\beta$ RII bands was normalized to the corresponding $\beta$-actin band. The gene expression ratio was normalized to $100 \%$ in normal veins, whereas in varicose veins it was expressed relative to normal controls. Mean values \pm standard deviations are presented. ${ }^{*} \mathrm{p}<0.001$, versus the normal vein wall.

reveal any significant difference in TGF- $\beta$ RII mRNA expression between men and women with varicose veins $(\mathrm{p}>0.05)$.

Western blot analysis of TGF- $\beta$ RII protein expression in the investigated tissues is shown in figure $2 \mathrm{a}$. TGF- $\beta$ RII is a protein with a molecular mass of about $75-85$ $\mathrm{kDa}$. The presence of such a band was demonstrated in the wall of normal veins (line 1 ) and varicose veins (line 2). Densitometric analysis of TGF- $\beta$ RII protein expression is shown in figure $2 \mathrm{~b}$. TGF- $\beta$ RII protein expression was significantly increased in the wall of varicose veins, 


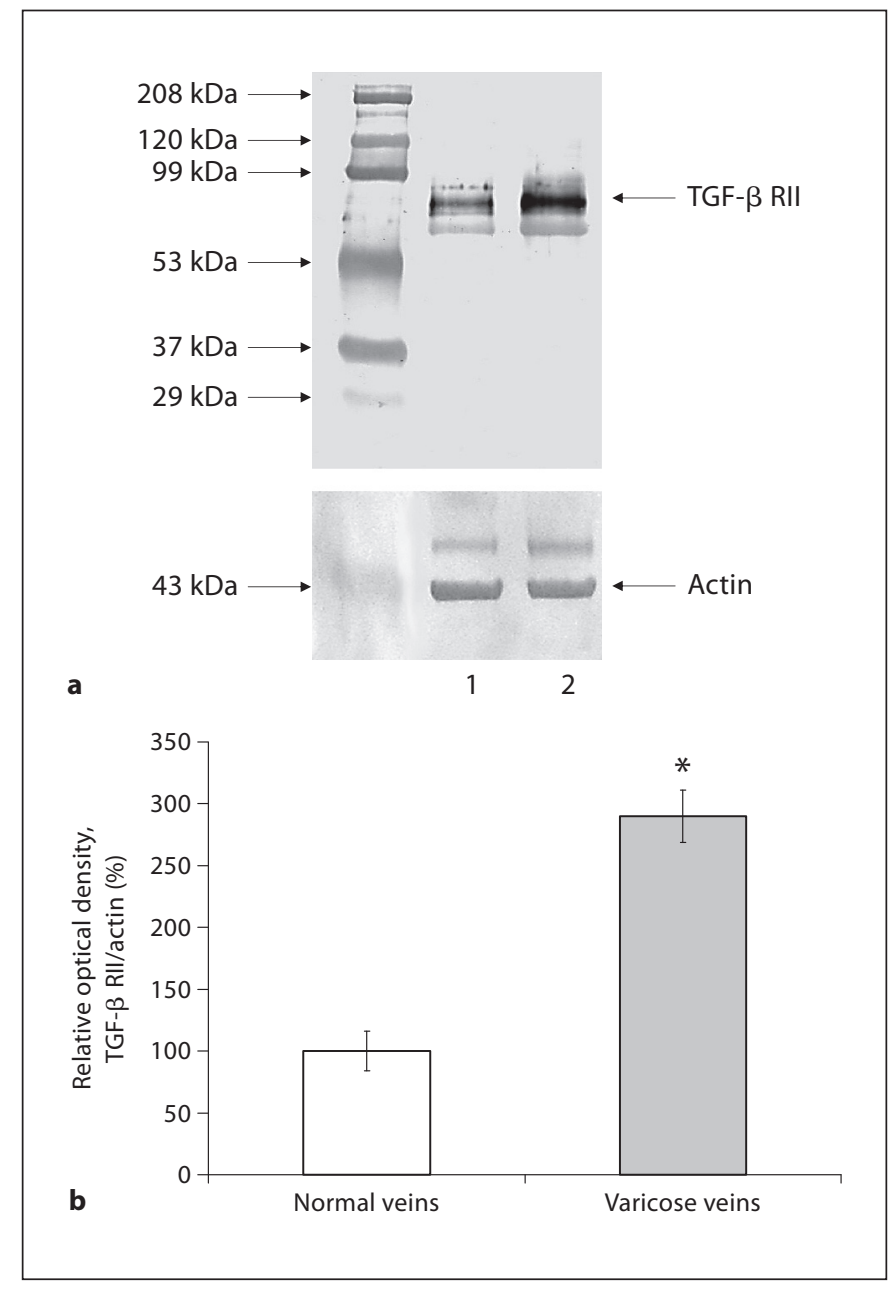

Fig. 2. a Western blot analysis of TGF- $\beta$ RII protein expression in the vein wall (lane 1 , normal veins; lane 2 , varicose veins). The same amount of protein extract $(20 \mu \mathrm{g})$ was run in each lane. Actin was used as a loading control. The molecular mass standards are indicated on the left side. $\mathbf{b}$ Densitometric analysis of TGF- $\beta$ RII protein expression from 12 control samples and 24 varicose vein samples. The optical density of TGF- $\beta$ RII bands was normalized to the corresponding actin band. The protein expression ratio was normalized to $100 \%$ in normal veins, whereas in varicose veins, it was expressed relative to normal controls. Mean values \pm standard deviations are presented. ${ }^{*} \mathrm{p}<0.001$, versus the normal vein wall.

when compared with the wall of controls $(\mathrm{p}<0.001)$. Further analysis revealed no gender differences in TGF- $\beta$ RII protein expression in the group of patients with varicose veins $(\mathrm{p}>0.05)$.

Western blot analysis of $\mathrm{p}-\mathrm{Smad} 2 / 3$ protein expression is shown in figure $3 \mathrm{a}$. Bands corresponding to a molecular mass of $55 \mathrm{kDa}$ were demonstrated in normal (line 1)

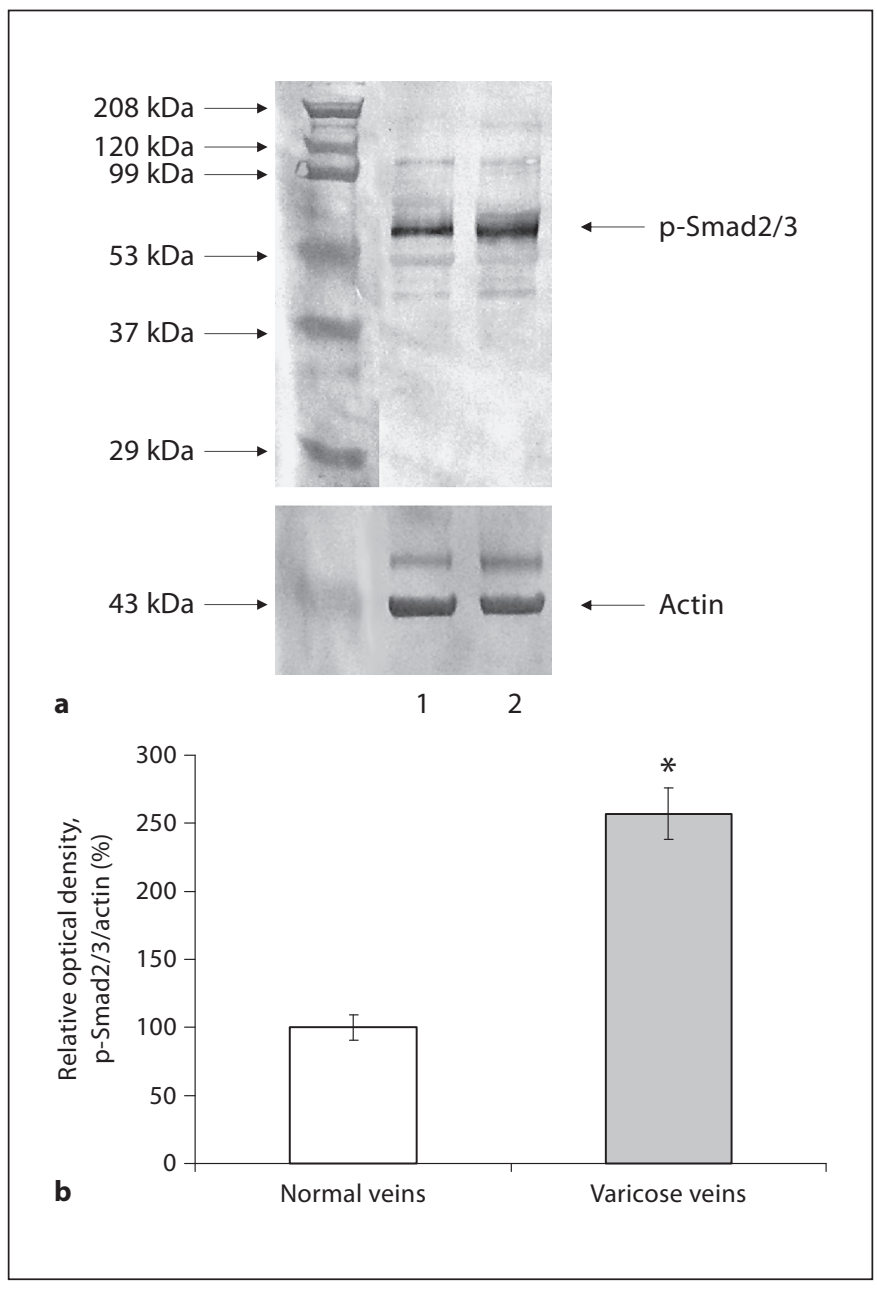

Fig. 3. a Western blot analysis of $\mathrm{p}-\mathrm{Smad} 2 / 3$ protein expression in the vein wall (lane 1, normal veins; lane 2 , varicose veins). The same amount of protein extract $(20 \mu \mathrm{g})$ was run in each lane. Actin was used as a loading control. The molecular mass standards are indicated on the left side. b Densitometric analysis of $\mathrm{p}$ Smad2/3 protein expression in 12 control samples and 24 varicose vein samples. The optical density of $\mathrm{p}-\mathrm{Smad} 2 / 3$ bands was normalized to the corresponding actin band. The protein expression ratio was normalized to $100 \%$ in normal veins, whereas in varicose veins, it was expressed relative to normal controls. Mean values \pm standard deviations are presented. ${ }^{*} \mathrm{p}<0.001$, versus the normal vein wall.

and varicose veins (line 2). Figure $3 \mathrm{~b}$ presents densitometric analysis of $\mathrm{p}-\mathrm{Smad} 2 / 3$ protein expression, which was significantly increased in the wall of varicose veins, when compared with the wall of normal veins $(\mathrm{p}<0.001)$. There was no significant correlation between the level of $\mathrm{p}$-Smad $2 / 3$ expression and gender in the group of patients with varicose veins $(p>0.05)$. 


\section{Discussion}

The TGF family consists of numerous isoforms. Among them, TGF- $\beta_{1}$ and TGF- $\beta_{3}$ are present in the cardiovascular system with a very low expression of the latter one, whereas TGF- $\beta_{1}$ belongs to the most powerful cytokines involved in vessel wall remodeling [6]. The process is noted as one of the key factors in varicose vein pathogenesis, with a potential role of TGF- $\beta_{1}$. Its increased mRNA level was demonstrated in varicose veins [8]. The growth factor protein content, as well as protein expression of TGF- $\beta_{1}$ latent and active forms, is also increased in varicose veins [7-9]. Furthermore, immunohistochemistry revealed increased staining for TGF- $\beta_{1}$ in tissue sections, as well as in cell cultures from varicose veins $[8,9,16]$. However, tissue responsiveness to TGF- $\beta_{1}$ depends on numerous factors, including TGF- $\beta$ RII expression and activation $[5,12]$.

The results of our study demonstrated increased TGF$\beta$ RII mRNA expression in the wall of varicose veins. The increased TGF- $\beta$ RII mRNA level was accompanied by the increased expression of TGF- $\beta$ RII protein. The receptor expression is modified by TGF- $\beta_{1}$ activity. It has been hypothesized that high levels of active TGF- $\beta_{1}$ maintain a feedback loop in which TGF- $\beta$ RII expression remains high [6]. If such a relation is present in the vein wall, increased TGF- $\beta$ RII expression can result from enhanced TGF- $\beta_{1}$ activity in the wall of varicose veins [9].

Increased TGF- $\beta$ RII expression may enhance TGF- $\beta_{1}$ binding. However, the growth factor-related metabolic response depends on receptor activation that leads to phosphorylation of receptor-related intracellular proteins Smad2 and Smad3 [5, 12]. The results of our study demonstrated increased protein expression of $\mathrm{p}-\mathrm{Smad} 2 / 3$ in varicose veins. Thus, increased expression and activation of TGF- $\beta$ RII may influence TGF- $\beta_{1}$-related ECM remodeling in the wall of varicose veins. Increase in
mRNA expression and protein content of collagen type I, as well as increase in contents of some glycosaminoglycans, e.g., chondroitin and dermatan sulfates, belong to biological effects of TGF- $\beta_{1}$ activity [17-19]. Such changes in ECM composition were also shown in the wall of varicose veins $[20,21]$.

CVI is associated with increased expression of estrogen and progesterone receptors in the wall of varicose veins in females [22]. In contrast, we did not reveal any gender-related difference in the TGF- $\beta$ signaling pathway in the vein wall. Different expression of sex hormone receptors may reflect different levels of estrogen and progesterone in females and males, whereas TGF- $\beta_{1}$ levels are not significantly different between men and women in healthy volunteers [23]. Furthermore, there is no correlation between TGF- $\beta$ RII mRNA and gender in other diseases [24].

Assessment of varicose veins in humans gives information only at an established level of the disease. Also, varicose veins are usually compared with normal veins collected from patients with another vascular pathology, e.g., atherosclerosis $[8,9,16]$ or CVI $[21,25]$. However, such control material is accepted in studies on varicose veins, because collection of normal veins during autopsy is related to mRNA degradation in tissue samples, whereas from brain death organ donors to different expression of effector genes [26, 27]. Moreover, animal models of varicose vein development are far from perfect, because all of them are based on induction of venous hypertension, which does not exactly reflect the disease pathogenesis [28].

According to the results of our study, we can conclude that increased TGF- $\beta$ RII expression and activation in the wall of varicose veins may be involved in ECM remodeling related to TGF- $\beta_{1}$ and supports its role in the disease pathogenesis.

\section{References}

1 Guex JJ, Myon E, Didier L, Nguyen Le C, Taieb C: Chronic venous disease: health status of a population and care impact on this health status through quality of life questionnaires. Int Angiol 2005;24:258-264.

$\longrightarrow 2$ Bergan JJ, Schmid-Schönbein GW, Smith PD, Nicolaides AN, Boisseau MR, Eklof B: Chronic venous disease. N Engl J Med 2006; 355:488-498

3 Naoum JJ, Hunter GC, Woodside KJ, Chen C: Current advances in the pathogenesis of varicose veins. J Surg Res 2007;141:311-316.
4 Schönherr E, Hausser HJ: Extracellular matrix and cytokines: a functional unit. Dev Immunol 2000;7:89-101.

5 Dabek J, Kulach A, Monastyrska-Cup B, Gasior Z: Transforming growth factor beta and cardiovascular diseases: the other facet of the 'protective cytokine'. Pharmacol Rep 2006;58:799-805.

6 Grainger DJ: Transforming growth factor beta and atherosclerosis: so far, so good for the protective cytokine hypothesis. Arterioscler Thromb Vasc Biol 2004;24:399-404.
7 Badier-Commander C, Couvelard A, Henin D, Verbeuren T, Michel JB, Jacob MP: Smooth muscle cell modulation and cytokine overproduction in varicose veins. An in situ study. J Pathol 2001;193:398-407.

-8 Jacob T, Hingorani A, Ascher E: Overexpression of transforming growth factor-betal correlates with increased synthesis of nitric oxide synthase in varicose veins. J Vasc Surg 2005;41:523-530. 
-9 Pascual G, Mendieta C, García-Honduvilla N, Corrales C, Bellón JM, Buján J: TGF-betal upregulation in the aging varicose vein. J Vasc Res 2007;44:192-201.

10 Jenkins G: The role of proteases in transforming growth factor-beta activation. Int Biochem Cell Biol 2008;40:1068-1078.

11 de Caestecker M: The transforming growth factor-beta superfamily of receptors. Cytokine Growth Factor Rev 2004;15:1-11.

12 Chin D, Boyle GM, Parsons PG, Coman WB: What is transforming growth factor-beta (TGF-beta)? Br J Plast Surg 2004;57:215221.

13 Park HJ, Galper JB: 3-Hydroxy-3-methylglutaryl CoA reductase inhibitors up-regulate transforming growth factor-beta signaling in cultured heart cells via inhibition of geranylgeranylation of RhoA GTPase. Proc Natl Acad Sci USA 1999;96:11525-11530.

14 Bradford MM: A rapid and sensitive method for the quantitation of microgram quantities of protein utilizing the principle of proteindye binding. Anal Biochem 1976;72:248254.

$\checkmark 15$ Laemmli UK: Cleavage of structural proteins during the assembly of the head of bacteriophage T4. Nature 1970;227:680-685.

16 Buján J, Gimeno MJ, Jiménez JA, Kielty CM, Mecham RP, Bellón JM: Expression of elastic components in healthy and varicose veins. World J Surg 2003;27:901-905.
17 Bassols A, Massagué J: Transforming growth factor beta regulates the expression and structure of extracellular matrix chondroitin/dermatan sulfate proteoglycans. J Biol Chem 1988;263:3039-3045.

18 Eghbali-Fatourechi G, Sieck GC, Prakash YS, Maercklein P, Gores GJ, Fitzpatrick LA: Type I procollagen production and cell proliferation is mediated by transforming growth factor-beta in a model of hepatic fibrosis. Endocrinology 1996;137:1894-1903.

19 Kenyon NJ, Ward RW, McGrew G, Last JA: TGF-betal causes airway fibrosis and increased collagen I and III mRNA in mice. Thorax 2003;58:772-777.

20 Sansilvestri-Morel P, Rupin A, Badier-Commander C, Kern P, Fabiani JN, Verbeuren TJ, Vanhoutte PM: Imbalance in the synthesis of collagen type I and collagen type III in smooth muscle cells derived from human varicose veins. J Vasc Res 2001;38:560-568.

21 Wolanska M, Sobolewski K, Glowinski S, Kowalewski R, Plonski A: Glycosaminoglycans of normal veins and their alterations in varicose veins and varicose veins complicated by thrombophlebitis. Eur Surg Res 2001; 33:28-32.

22 Mashiah A, Berman V, Thole HH, Rose SS, Pasik S, Schwarz H, Ben-Hur H: Estrogen and progesterone receptors in normal and varicose saphenous veins. Cardiovasc Surg 1999;7:327-331.
23 Young DG, Skibinski G, Mason JI, James K: The influence of age and gender on serum dehydroepiandrosterone sulphate (DHEAS), IL-6, IL-6 soluble receptor (IL-6 sR) and transforming growth factor beta 1 (TGFbeta1) levels in normal healthy blood donors. Clin Exp Immunol 1999;117:476-481.

24 Park D 2nd, Son HJ, Song SY, Choe WH, Lim YJ, Park SJ, Kim JJ, Kim YH, Rhee PL, Paik SW, Rhee JC, Choi KW: Role of TGF-beta 1 and TGF-beta type II receptor in gastric cancer. Korean J Intern Med 2002;17:160-166.

25 Kowalewski R, Sobolewski K, Wolanska M, Gacko M: Matrix metalloproteinases in the vein wall. Int Angiol 2004;23:164-169.

26 Bauer M, Gramlich I, Polzin S, Patzelt D: Quantification of mRNA degradation as possible indicator of postmortem interval - a pilot study. Leg Med (Tokyo) 2003;5:220227.

27 Schuurs TA, Gerbens F, van der Hoeven JA, Ottens PJ, Kooi KA, Leuvenink HG, Hofstra RM, Ploeg RJ: Distinct transcriptional changes in donor kidneys upon brain death induction in rats: insights in the processes of brain death. Am J Transplant 2004;4:19721981.

28 Bergan JJ, Pascarella L, Schmid-Schönbein GW: Pathogenesis of primary chronic venous disease: insights from animal models of venous hypertension. J Vasc Surg 2008;47: 183-192. 